\title{
PHONEMIC DISCRIMINATION AND ITS RELATION TO PHONOLOGICAL DISORDER
}

\section{Discriminação fonêmica e sua relação com o transtorno fonológico}

\author{
Karine Leyla de Castro Oliveira ${ }^{(1)}$, Ranilde Cristiane Cavalcante Costa ${ }^{(2)}$
}

\begin{abstract}
It was performed a nonsystematic review on the importance of the phonemic discrimination to the phonological acquisition and its relation to the phonological disorder. Studies indicate that phonemic discrimination represents an essential ability in the process of acquiring sounds of speech and that children with phonological disorder present difficulties in that ability.
\end{abstract}

KEYWORDS: Auditory Perception; Speech Perception; Speech Disorders; Articulation Disorders; Language

\section{INTRODUCTION}

Discrimination, topic of this review, is the process of differentiation of acoustically similar sounds with different frequency, duration and/or intensity in which precisely these differences lie the information carried by the sound ${ }^{1}$. When discrimination is related to speech sounds, two terms are found in the literature: auditory discrimination and phonemic discrimination. Conceptually, the auditory discrimination is defined as the ability to auditorily distinguish the difference between the sounds of speech ${ }^{2}$. Already the phonemic discrimination can be defined as the ability of the individual to perceive minimal acoustic differences present in speech sounds ${ }^{3}$.

Although two different terms are used in the literature, both refer to the ability to discriminate between two speech sounds with minor differences. Throughout the text, the reader will find the two classifications - according to the nomenclature used on respective study. For the current study, the term phonemic discrimination was adopted based

(1) Undergraduate in Speech therapy course of Universidade Estadual de Ciências da Saúde de Alagoas - UNCISAL Maceió (AL), Brasil.

(2) Speech therapist; professor of the speech pathology department of Universidade Estadual de Ciências da Saúde de Alagoas - UNCISAL - Maceió (AL), Brasil; Master Degree in Human Communication Disorders by Universidade Federal de São Paulo - UNIFESP.

Conflict of interest: non-existent on the grounds that it involves the ability to distinguish differences marked by distinctive features with binary value oppositions. These oppositions between the distinctive features with binary values have been described in a test of phonemic discrimination with figures for the following combinations: [+sonant] and [-sonant], [+appox] and [-approx], [+ cont] and [-cont] ; [+voice] and [-voice], and in possible combinations of place: [labial] and [cor], [cor] and [dorsal], [labial] and [dorsal], [cor + ant] and [cor - ant] ${ }^{4}$.

Phonemic discrimination enables the perception of differences between the distinctive features and this perception is essential for the acquisition of speech sounds. This acquisition will only occur when there are conditions in which these sounds are discriminated from each other, enabling oral expression $^{5}$. As discrimination and the learning process of a phoneme develop, improvement and perceptual reorganization for the acquisition of the different phonemes are observed ${ }^{6,7}$.

The discriminative and procedural deficiencies related to the period of phonological acquisition could compromise the incorporation and organization of speech sounds ${ }^{3}$. Based on this, one can hypothesize that the disorder in the production of sounds is related to a difficulty in phonemic discrimination ${ }^{8}$.

Considering that phonemic discrimination is an important factor in the phonological acquisition, the present study aimed to conduct a nonsystematic literature review on the importance of phonemic discrimination for the acquisition of speech sounds and its relationship with phonological disorders. 


\section{METHOD}

The articles used for this nonsystematic review were selected through literature search of texts indexed in the following databases: LILACS (Latin American and Caribbean Health Sciences), Medline, SciELO (Scientific Electronic Library Online), PubMed, and CAPES journals. Books, conference proceedings, monographs, dissertations and doctoral theses were also considered. There was no restriction on the established period for the review.

The following combinations of descriptors were used on the bibliographic search: auditory perception and speech disorders; auditory perception and language; auditory perception and articulatory disorders; auditory perception and speech discrimination; auditory perception and speech discrimination tests; auditory perception and language development disorders; speech and language disorders; speech disorders and articulatory disorders; speech disorders and speech discrimination; speech disorders and speech discrimination tests; speech disorders and language development disorders; language and articulatory disorders; language and speech discrimination; language and speech discrimination tests; language and language development disorders; articulatory disorders and speech discrimination; articulatory disorders and speech discrimination tests; articulatory disorders and language development disorders; speech discrimination and speech discrimination tests; speech discrimination and language development disorders; speech discrimination tests and language development disorders. All terms used in the search were extracted from Descritores em Ciências da Saúde (Descriptors in Health Sciences - DeCS). The terms phonemic discrimination and phonological disorders were not used because they are not included in DeCs.

Original articles and reviews of literature were included. The bibliographic search revealed that most of the studies related to phonemic discrimination investigated this ability in individuals with hearing loss, specifically in cochlear implant users. Therefore, it was necessary to select the obtained articles excluding those which central theme was unrelated to the purpose of the current study. As the research progressed, references cited in the documents already surveyed were also consulted and added to this nonsystematic review.

Twenty one articles remained after applying the selection criteria. These articles were published in the following journals: American Journal of Otology; Brazilian Journal of Otorhinolaryngology; CEFAC; Clinical Linguistics \& Phonetics; Fono Atual;
International Journal of Language \& Communication Disorders; Jornal da Sociedade Brasileira de Fonoaudiologia; Journal of Child Language; Journal of Speech, Language, and Hearing Research; Nature Reviews - Neuroscience; Pro Fono; Revista Brasileira de Otorrinolaringologia; Revista da Sociedade Brasileira de Fonoaudiologia; Psicologia Escolar e Educacional; e Psicologia: Reflexão e Crítica.

\section{LITERATURE REVIEW}

Integrity of the organic structures involved in the detection, reception, conduction, and interpretation processes is necessary for a sound to be perceived. Shortly after birth, babies are able to detect consonant contrasts of any language, and later become able to selectively discriminate phonemes of the language that they ate exposed to ${ }^{9}$. Four-month old babies are able to distinguish phonemic contrasts in sound signals as shown by changes in heart rate. Studies suggest that children between one and four years of age are able to distinguish most pairs of sounds ${ }^{10}$.

The fact that babies are able to discriminate acoustic aspects of speech suggests that they can divide an almost continuous acoustic stimulus into distinct segments. This ability to transform speech into distinct elements is the basis for language competence $^{10}$.

The perception of speech sounds involves a complex system that goes beyond the reality of simple acoustic signal detection ${ }^{1}$. For speech to be perceived, the steps of audibility, reception, discrimination, recognition and memory are necessary 5 . The difficulty in understanding speech sounds may be related to the occurrence of phonological alterations during infancy ${ }^{11}$.

Among the auditory aspects, phonemic discrimination is a major factor in the acquisition of speech sounds - the mental representation and storage of linguistic stimuli is established through the reception, analysis and organization of auditory information processing ${ }^{4,12}$. Therefore, the ability to discriminate phonemes is critical to the phonological acquisition ${ }^{3}$.

Although the literature indicates the importance of phonemic discrimination for the acquisition of speech sounds, hearing assessment primarily concerns to define the presence or absence of a hearing loss, focusing on aspects related to acuity. By recognizing the importance of phonemic discrimination for phonological acquisition, one sees the need to assess this ability, extending the commonly performed auditory investigation.

In addition to phonemic discrimination, the acquisition of speech sounds depends on neuromuscular 
integrity and maturation. Thus, sensory and motor aspects are involved in the standard learning process of a language. It is through the association of auditory aspects to the motor articulatory gesture that the phonemes of the language are memorized and become ready to be used in the speech ${ }^{3}$.

During development, children perceive sounds and at approximately three years of age children exhibit an increasingly visible progress in their speech production. At this stage, children improve the movement of oral articulators and expand their oral and metalinguistic universe so that in the period between three and six years of age they can be understood by those who are not part of their social environment ${ }^{13}$.

The phonological acquisition process is complex and involves different skills. Children need to develop skills related to hearing, such as phonemic discrimination, and skills related to orofacial muscles for an adequate movement of the articulators during speech. This shows that the perception-production dyad is critical during the process of phonological acquisition and problems related to hearing and articulatory praxis can affect the stabilization of the phonological system.

In typical phonological acquisition, the mastery of the phonological system of a target language is spontaneously reached, in an age sequence common to most children (between four and six years of age). On the other hand, disordered phonological acquisition is the one in which the adequacy of the phonological system is not spontaneously achieved and/or is not achieved in the same sequence observed in most children ${ }^{14}$.

Phonological disorder is the most common speech disorder found in children ${ }^{16,17}$. Although the etiological markers are being investigated, its etiology is still unknown ${ }^{18}$. The observed deficit in phonological disorder may be associated with difficulties at various levels such as discrimination of phonetic differences, recognition of phonological contrasts, and lexical representation of these contrasts, which causes alterations in speech sounds and articulatory imprecision ${ }^{19}$.

Considering that the deficit in phonological acquisition may be associated with deficits in the discrimination of phonetic differences, studies have investigated the phonemic discrimination in children with phonological disorders. Although in a small number, studies indicate that these children have difficulties in the ability of discrimination, which creates an inability to differentiate between two speech sounds with minimal acoustic differences $3,8,20,21$.

The study of phonemic discrimination in children with phonological disorders shows a relationship between the disordered phonemes in speech and the errors identified by tests of auditory discrimination. The study that carried out this investigation observed that $23.53 \%$ of children showed accuracy inferior to $62 \%$ on the test and found that the same phonemes that were disordered in the test were also disordered in speech ${ }^{21}$.

The study of phonemic discrimination associated with auditory processing showed that children with speech disorders had difficulties in these two areas. Thus, it is known that deficits in auditory processing impair the ability to discriminate phonemes, and the signs of these alterations can impact on the appropriate use of contrastive speech sounds ${ }^{3}$.

The association between phonological disorder and difficulties in phonemic discrimination and auditory processing highlights that these two abilities should be considered in speech therapy. Thus, one can infer that the inability to discriminate sounds is related to a possible causal factor for this disorder.

The severity of phonological disorders is related to auditory discrimination. A study found that individuals with mild disorder showed better performance on auditory discrimination tasks as compared to those with mild-moderate or moderate-severe disorder. This suggests a possible relationship between the severity of the phonological disorder and auditory discrimination. The literature indicates that the severity of phonological disorder is also associated with greater difficulties in phonological awareness ${ }^{22,23}$, articulatory praxis ${ }^{22}$, expressive vocabulary ${ }^{24}$, and personal awareness of phonological disorder ${ }^{23}$.

Measurement of phonological disorder severity is an important information to be considered in clinical practice as it can be used to monitor the progress during therapy treatment. In addition, severity also represents an important predictor of the difficulties that children with phonological disorders may exhibit in linguistic, metalinguistic and praxic skills.

The observed deficits in phonemic discrimination of children with phonological disorders may impact the performance of these children on tasks that assess metalinguistic competence, as the latter refers to the ability to analyze words according to different sound units that compose them and which can be consciously manipulated ${ }^{25}$. The development of phonological awareness can be influenced by speech perception ${ }^{26}$, for which the integrity of the physiological auditory mechanisms is fundamental ${ }^{27}$.

Most studies report poorer performance of children with phonological disorders in phonological awareness skills ${ }^{22,28-33}$. This difficulty was reported by studies analyzing from phonological sensitivity ${ }^{28,29}$ to phonemic awareness ${ }^{31,34}$ and observed 
that this difficulty persists even after the speech therapy ${ }^{30}$. Studies have also shown the effectiveness of the combination of different strategies for stimulating phonological awareness and target sound production on the treatment of phonological disorder ${ }^{35,36}$.

Thus, during the speech therapy with children with speech disorders, the Speech-Language Therapist should consider the stimulation and the phonological awareness of target sounds along with the associated auditory processing as this approach allows the organization of mental representation of speech sounds, resulting in a better speech production.

The association between phonological awareness and acquisition of reading and writing makes the children with phonological disorder at risk for difficulties during the literacy process ${ }^{5,37}$. Studies have shown that even after speech therapy and the overcoming of speech disorder, children who have had phonological disorders during infancy have a deficit in the phonological process ${ }^{37}$ and poorer reading and writing performance ${ }^{32}$. Considering the possibility that children with phonological disorders exhibit alterations in phonological awareness, and consequently difficulties in acquiring reading and writing, phonological disorder deserves attention, especially along the school years ${ }^{38}$.

Therefore, an early diagnosis of the phonological disorder is important. Furthermore, the SpeechLanguage Pathologist should not be limited only to test and treat the manifestations in speech, since this disorder can be associated with difficulties in different perceptual skills, including phonemic discrimination.

Considering the limited number of studies investigating the phonemic discrimination in children with phonological disorders, further clinical research should be carried out in order to compare the performance of phonemic discrimination of children with phonological disorders and their peers without speech disorders.

\section{CONCLUSION}

Based on the analysis of the articles that composed this review, it can be concluded that phonemic discrimination represents an essential ability in the acquisition of speech sounds and children with phonological disorders exhibit difficulties in the phonemic discrimination ability.

\section{RESUMO}

Foi realizada uma revisão não sistemática sobre a importância da discriminação fonêmica para a aquisição dos sons da fala e sua relação com o transtorno fonológico. Os estudos indicam que a discriminação fonêmica representa uma habilidade essencial no processo de aquisição dos sons da fala e que as crianças com transtorno fonológico apresentam dificuldade nesta habilidade.

DESCRITORES: Percepção Auditiva; Discriminação da Fala; Distúrbios da Fala; Transtornos da Articulação; Linguagem

\section{REFERENCES}

1. Russo I, Behlau M. Percepção da fala: análise acústica do português brasileiro. São Paulo: Ed. Lovise; 1993.

2. Rodrigues EJB. Discriminação auditiva - Normas para avaliação de crianças de 5 a 9 anos. São Paulo: Ed. Cortez; 1981.

3. Attoni TM, Quintas VG, Mota HB. Avaliação do processamento auditivo e da discriminação fonêmica em crianças com desenvolvimento fonológico normal e desviante. Braz. J. Otorhinolaryngol. 2010; 76(6):762-8.
4. Santos-Carvalho B, Mota HB, Keske-Soares M. Teste de figuras para discriminação fonêmica: Uma proposta. Rev Soc Bras Fonoaudiol. 2008;13(3):207-17.

5. Santos-Carvalho B. Teste de figuras para discriminação fonêmica: proposta e aplicação. [Dissertação de mestrado]. Santa Maria (RS): Universidade Federal de Santa Maria. Centro de Ciências da Saúde. 2007.

6. Kuhl, PK. Early language acquisition: Cracking the speech code. Nat. Rev. Neurosci. 2004;5:831-43.

7. Philips DP. Central auditory processing: a view from auditory neuroscience. Am J Otology. 1995;16: 338-52. 
8. Santos B, Bagetti T, Kist FRZ, Mota HB, KeskeSoares M. Relação entre o grau de severidade do desvio fonológico e a discriminação auditiva. In: V Congresso Internacional, XI Congresso Brasileiro e I Encontro Cearense de Fonoaudiologia. 2003, Fortaleza. Resumos. Fortaleza: 2003.

9. Santos-Carvalho B, Mota HB, Keske-Soares M, Attoni TM. Habilidades de discriminação auditiva em crianças com desvios fonológicos evolutivos. Pró-Fono R. Atual. Cient. 2010; 22(3) 311-7.

10. Northern JL, Downs MP. Audição em crianças. São Paulo: Manole; 1989.

11. Eilers RE, Oller DK. The role of speech discrimination in developmental sound substitutions. Journal of Child Language. 2008; 3(3) 319-29.

12. Magalhães ATM, Paolucci JF, Ávila CRB. Estudo fonológico e da percepção auditiva de crianças com ensurdecimento de consoantes. Fono Atual. 2006;8(35):22-9.

13. Wertzner HF, Galea DES, Almeida RC. Uso do processo fonológico de simplificação de velar em crianças de 2,1 a 3,0 anos de idade. J. Bras. Fonoaudiol. 2001;2(8): 233-8.

14. Lamprecht RR. Sobre os desvios fonológicos. In: Lamprecht RR, organizador. Aquisição fonológica do português: perfil de desenvolvimento e subsídios para terapia. Porto Alegre: Artmed; 2004. p. 193-212.

15. Caumo DTM, Ferreira MIDC. Relação entre desvios fonológicos e processamento auditivo. Rev. Soc. Bras. Fonoaudiol. 2009; 14(2):234-40.

16. Lima BPS, Guimarães JATL, Rocha MCG. Caracteristicas epidemiológicas das alterações de linguagem em um centro fonoaudiológico do primeiro setor. Rev Soc Bras Fonoaudiol. 2008;13(4):376-80.

17. Goulart BNG, Ferreira J. Teste de rastreamento de alterações de fala para crianças - Terdaf. Pró-Fono R. Atual. Cient. 2009;21(3):231-6.

18. Shriberg LD, Kent RD, Karlsson HB, McSweeny JL, Nadler CJ, Brown RL. A diagnostic marker for speech delay associated with otitis media with effusion: backing of obstruents. Clin Linguist Phon. 2003;17(7):529-47.

19. Wertzner HF, Oliveira MMF. Semelhanças entre sujeitos com distúrbio fonológico. Pró-Fono R. Atual. Cient. 2002;14(2): 143-52.

20. Santos B. Habilidade de discriminação auditiva em crianças com desvios fonológicos evolutivos. [Monografia - especialização em Fonoaudiologia]. Santa Maria (RS). Universidade Federal de Santa Maria; 2005.

21. Keske-Soares M, Mota HB, Costamilan CM. Discriminação auditiva em crianças com desvios fonológicos evolutivos. In: 9o Congresso Brasileiro de Fonoaudiologia, 2001; Guarapari. Anais eletrônicos. Guarapari: Soc. Bras. De Fono; 2001. 22. Souza TNU. Gravidade do transtorno fonológico, consciência fonológica e praxia articulatória em pré escolares. [Dissertação de mestrado]. São Paulo (SP): Universidade Federal de São Paulo. Programa de Pós-Graduação em Ciências dos Distúrbios da Comunicação Humana. 2010.

23. Dias RF, Mota HB, Mezzomo CL. A consciência fonológica e a consciência do próprio desvio de fala nas diferentes gravidades do desvio fonológico. Rev. CEFAC. 2009;11(4):561-70.

24. Athayde ML, Carvalho Q, Mota HB. Vocabulário expressivo de crianças com diferentes níveis de gravidade de desvio fonológico. Rev CEFAC. 2009;11 (Supl2):161-8.

25. Barrera SD, Malu MR. Consciência metalinguística e alfabetização: um estudo com crianças da primeira série do ensino fundamental. Psicol. Refl. E Crít, 2003:16(3): 491-502.

26. Rvachew S, Grawburg M. Correlates of phonological awareness in preschoolers with speech sound disorders. J Speech Lang Hear Res. 2006:49(1):74-87.

27. Watson BU, Miller T. Auditory perception, phonological processing and reading ability/ disabilities.JSpeech Lang HearRes 1993;36:850-63. 28. Costa RC, Avila CR. Competência lexical e metafonológica em pré-escolares com transtorno fonológico. Pró-Fono. 2010;22(3):189-94.

29. Costa RCC, Souza TN, Avila CR. Sensibilidade fonológica para rima e aliteração em pré-escolares com transtorno fonológico. J. Soc. Bras. Fonoaudiol. 2011;23(2):129-34.

30. Mota HB, Melo-Filha MGC. Habilidades em consciência fonológica de sujeitos após realização de terapia fonológica. Pró-Fono $R$. Atual. Cient. 2009;21(2):119-24.

31. Marchetti PT, Mezzomo CL, Cielo CA. Desempenho em consciência silábica e fonêmica em crianças com desenvolvimento de fala normal e desviante. Rev. CEFAC. 2010;12(1):12-20.

32. Mota HB, Melo Filha MGC, Lasch SS. A consciência fonológica e o desempenho na escrita sob ditado de crianças com desvio fonológico após realização de terapia fonoaudiológica. Rev CEFAC. 2007;9(4):477-82.

33. Spíndola RA, Payão LM, Bandini $H H$. Abordagem fonoaudiológica em desvios fonológicos fundamentada na hierarquia dos traços distintivos e na consciência fonológica. Rev CEFAC. 2007;9(2):180-9.

34. Souza TN, Avila CR. Gravidade do transtorno fonológico, consciência fonológica e praxia articulatória em pré-escolares. Rev Soc Bras Fonoaudiol. 2011;16(2):182-8. 
35. Holm A, Farrier F, Dodd B. Phonological awareness, reading accuracy and spelling ability of children with inconsistent phonological disorders. Int J Lang Comm Disord. 2008;43:300-22.

36. Denne M, Langdown N, Pring T, Roy P. Treating children with expressive phonological disorders: does phonological awareness therapy work in the clinic? Int J Lang Comm Disord. 2005;40:493-504.
37. Salgado C, Capellini SA. Desempenho em leitura e escrita de escolares com transtornos fonológicos. Psicol Esc Educ. 2004;8(2):179-88.

38. Mezzomo CL, Mota HB, Dias RF. Desvio fonológico: aspectos sobre produção, percepção e escrita Rev. Soc. Bras. Fonoaudiol. 2010; 15(4):554-60.

http://dx.doi.org/10.1590/S1516-18462012005000044

Received on: July 12, 2011

Accepted on: October 31, 2011

Mailing Address:

Karine Leyla de Castro Oliveira

Conjunto Graciliano Ramos, Qd I-5, Rua 44, N 34, Lote 11 - Cidade Universitária

Maceió - AL - Brasil

CEP: 57073-340

E-mail: karineleyl@ hotmail.com 